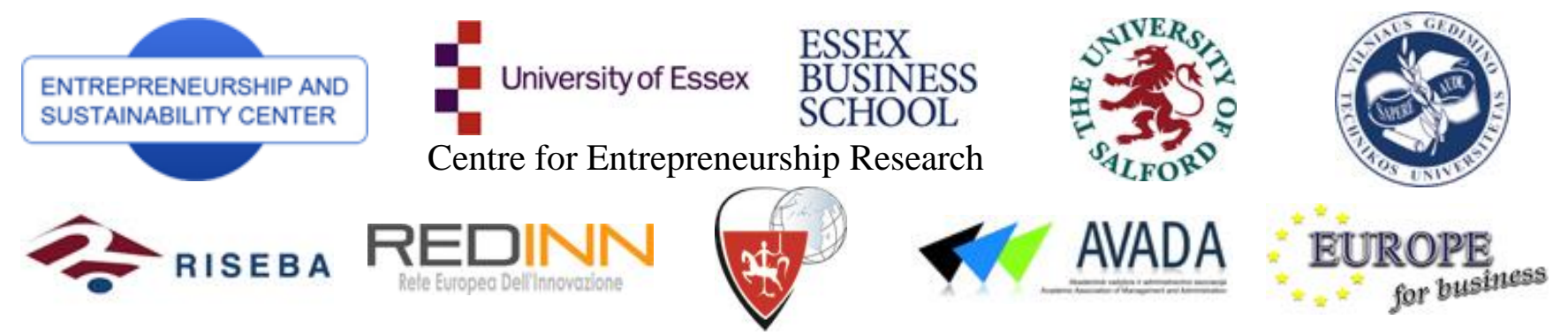

ENTREPRENEURSHIP AND SUSTAINABILITY ISSUES

ISSN 2345-0282 (online) http://jssidoi.org/jesi/aims-and-scope-of-research/

2013 Volume 1(1): 10-22

http://dx.doi.org/10.9770/jesi.2013.1.1(2)

\title{
THE ROLE OF CREATIVITY IN SUSTAINABLE BUSINESS
}

\author{
Mindaugas Laužikas', Rasa Mokšeckienè ${ }^{2}$ \\ ${ }^{1,2}$ International Business School at Vilnius University \\ Sauletekio av. 22, LT-10225 Vilnius, Lithuania
}

E-mails: '1mindaugas.lauzikas@gmail.com; ${ }^{2}$ rasa.mokseckiene@tvm.vu.lt

Received 22 February 2013; accepted 18 March 2013

\begin{abstract}
The present article aims to examine a set of creativity-related concepts, dimensions, patterns, different ways and techniques of generating ideas, developing talents, funding opportunities as well as protecting intellectual property rights, and, in particular, how all these factors affect the economy and sustainable business. To continue, there is the importance of intercultural dialogue analysed while opening co-operation and partnership opportunities in various regions, mobility opportunities among artists as well as developing skills, creativity, innovations, and entrepreneurship. Entrepreneurship emerges as an important factor in a rapidly changing world of business and transforming creative ideas into a value-added. There is a significant number of university studies, creative businesses and/ or entrepreneurship programs tackled via presenting programs at universities, while the symbiosis 'Business-Arts' brings new colours to the image of creativity: investments in human resources, trainings, researches, lifelong learning and entrepreneurship open up new opportunities of merging arts and business and concentrating a wide range of artistic and business talents in one area (incubators and/ or clusters of arts) where arts and business complement each other. Thus, the research question: how does the creativity affect a sustainable business performance in Lithuania? A solid Global Entrepreneurship Monitor methodology and data mainly for the year of 2011 (including some newest trends for 2012) were used in order to light up the main problems and trends of enhancing the creativity in Lithuanian companies while creating a higher value-added and competitive advantage.
\end{abstract}

Keywords: Creativity, Culture, Arts, Sustainability, Business Development, Entrepreneurship, European Union.

Reference to this paper should be made as follows: Laužikas, M.; Mokšeckienè, R. 2013. The role of creativity in sustainable business, Journal of Entrepreneurship and Sustainability Issues 1(1): 10-22.

http://dx.doi.org/10.9770/jesi.2013.1.1(2)

JEL Classification: A13, A20, D22, D23, D83, J24, L14, L26, M12, M14, M21, O31.

\section{Introduction}

"Creativity", "Culture", "Arts", "Talents" are interrelated terms that are seldom tackled in the context of sustainable business development. Thus, the creativity should be analysed, based on a holistic approach where each element plays an important role, because of its specific knowledge, necessary for developing innovative product, process or service for a constantly changing market (Ashley, Oliver 2010). As it is stated by Gong et al. (2009), the principle focus should be on the employees' creativity, driven by constant learning and developing new skills. Mainemelis (2010) emphasizes the number of new ideas as they should be translated to innovations, while Meyers and Gerstman (2007) advice to scrutinize the concept of creativity by taking into consideration the 
cases of different creative industries. Scholars agree that the creativity is crucial for self-realization and selfactualization, and Hill (2003) specifies the generation of novel ideas as a principle output of creativity. Based on such logics, innovation is a process of transforming ideas into value.

The culture which has been formatting for centuries (arts, music, literature, tradition) has united Europe; the European Union in today's global world is known for its cross-cultural unity and respect for each other, because the globalization has opened a door to intercultural exchanges, freedom of movement and knowledge of cultures. The peace and mutual understanding in Europe is to ensure a multicultural society, where there is the tolerance, solidarity and other values enhanced. The European Union aims to promote the creativity in a sustainable development of cultural and artistic projects, the awareness of European cultural heritage, multilingualism, youth exchanges, learning, sharing knowledge on European cultures, restoration of a cultural heritage, and the development of information society. For many years the European Union provides a financial and technical support for cultural projects in developing regions as well as pays a lot of attention to human rights. In 1989, there was a free movement of the European audio-visual content within EU borders established, being supported by the adoption of the 'Television without Frontiers' Directive, which has contributed to a cultural diversity. Within the communication of the European Commission (2007), oriented to the ratio of culture and Europe in the global world and mainly based on the Green Paper (European Commission 2010a), the main focus is on such fields as the acquaintance with culture, the use of creativity and increasing a value-added. The European Commission, relying on its past achievements and strengthening current activities in the European agenda identifies the necessity of encouraging a cultural diversity and intercultural dialogue (promoting artists, culture employees' employability and adaptability as well as the mobility of art works in the global economy). The encouragement of culture as a catalyst for the creativity in the implementation of the Lisbon strategy of growth and jobs creation (cultural and creative industries significantly contribute to the growth of GDP and employment in the EU; this is a competitive advantage of the economy (European Commission 2007)) is to promote the creativity in education, cultural employees' skills related to management and strengthening entrepreneurship, sustainable development of social and economic investments, particularly in creating jobs and increasing the attractiveness of cities.

The promotion of culture is a vital element of the European Union's international relations (the diffusion of knowledge on the European culture through the dissemination of cultural dialogue and exchange, supporting the access for cultural goods and services from developing countries to European and other markets, providing a technical and financial support, protecting the cultural diversity, cultural integration to the developing countries' educational curricula).

The respect for cultural diversity and the ability to share common values have guaranteed the peace, prosperity, sustainability and solidarity in the EU (European Commission 2010b). After the adoption of the European Agenda for the Culture in 2007, the Member States of the European Union were invited to work together to promote and support a cultural diversity and an intercultural dialogue as an important aspect of the European Union's international relations. The success of the European Cultural Agenda Report (European Commission $2010 b$ ) is evaluated by the ability of Member States to achieve the objectives and is based on the Member States' submitted national reports. In order to achieve their goals, the progress was made in many areas: the promotion of cultural diversity and intercultural dialogue, the awareness raising and political discussion on the cultural dialogue-related issues led to the creation of new political arrangements and structures, and the political agreement on the need to improve intercultural competences as well as to facilitate the intercultural dialogue in external relations of the European Union (European Commission 2010b). The achievement of this goal has led to the greater mobility of representatives of arts and culture, to the prevention and combating study on the illicit trade in cultural values and synergies between the culture and education (knowing better different cultures and a sustainable development of creativity).

In order to ensure the solidarity via the support of a linguistic diversity, there were dialogue platforms created for the business and society, such as 'Europeana' (launched in 2008), which is the online library of the European Union, media literacy concepts or the initiation of the label marking the sites that are important in terms of values, history and heritage. The year of 2008 was named the European Year of the Intercultural Dialogue with a special focus on multilingualism. Within the development of cultural and creative sectors, manufactured and sold goods and services are protected by the integrity of a cultural content, i.e. copyright. The growth of digital technologies encourages thinking about the protection of cultural goods and services against the piracy. The 
cultural diversity is not only the production and trade; it includes consumers' choice, the increase in co-operation and cultural dialogue, and the access to culture.

The balance of culture influences development processes that support cultural values, such as minority languages, traditional rituals, art creations, heritage buildings and places of interest. Therefore, the creation of the adequate economic, legal and social environment is needed in order: to ensure the developers' creative potential, to link the culture and education, and to increase the production and creation potential of cultural services, to promote the private and public investment in the cultural sector, to support small and micro enterprises while encouraging them to use the creativity in practice, to promote the unimpeded cross-border mobility of cultural employees in accordance with the UNESCO Convention on Cultural Diversity (European Parliament 2008).

While promoting the culture as an important European dimension in international relations more financial resources are allocated to the culture and regional co-operation of third countries, due to a stronger focus on the European Neighbourhood Policy and the Union for the Mediterranean. Candidate countries are encouraged to restore their heritage, the political partnership dialogue; the co-operation among Eastern countries is initiated, and the role of the culture in politics is strengthened through encouraging equivalent exchanges among developing countries in the field of culture and promoting the preferential mode. In addition, the bilateral partnership with other developed and growing countries is fostered, the preparatory action 'MEDIA International' is launched, which aims to promote the mobility of the film and audio visualization and cooperation among professionals from European and third countries.

While promoting cultural exchanges, co-operation, development policies or external relations the cultural dimension crossing the boundaries of the European Union should be strengthened. The respect for other cultures promotes the solidarity, opens new possibilities of international economic and social relations, mobility exchanges and the access to goods and services of various cultures. In sustainable development of the concept of multicultural society in the European Union, Lithuania and worldwide it is becoming important to prepare a larger number of innovative and creative people, able to understand, adapt and find the mutual relationship between arts and rapidly changing global business world.

\section{The interaction of arts and business across universities and todays' market needs}

In recent years the installation of creative industries, creative businesses and entrepreneurship programs at universities worldwide takes on the growing momentum. This trend is because of changes in the today's globalized world that encourage to create a better future, i.e. a sustainable business is impossible without the creativity, because creativity is not just paintings or other arts, creativity is the generation of new ideas, talents, skills, underlying new achievements, technologies and etc. Thus, university programs distinguished by the originality and creativity are determined by national policies, local traditions, and etc. While reviewing universities worldwide (where the undergraduate and/or graduate programs related to the encouragement of creativity, creative industries management and administration, entrepreneurship and etc. are developed) there were universities of various regions reviewed: Asia, North and South America, Europe and Pacific Ocean countries. The choice of university was based on the fact that these universities were oriented to programs of arts and/ or business, mainly focusing on the creativity and entrepreneurship. For example, the Kingston University in Great Britain, London, develops creative industries and creative economy postgraduate studies (out of 24 programs 16 are related to the creative economy) that are associated with the variety of creative industries, such as "Advertising and Creative Economy", "Design and Creative Economy", "Journalism and Creative Economy" and other programs oriented to creative industries and creative economy.

Entrepreneurship is developed within cultural management and cultural and creative sectors' activities, scientific researches, new business approaches as well as financial models and management of creative economics: such discipline is taught at the Institute for Creative and Cultural Entrepreneurship of the Goldsmiths College at the University of London. This program introduces creative and cultural entrepreneurship activities, the integration of entrepreneurship in the context of creative activities and the development of new business. According to the Institute's point of view, entrepreneurship is the value creation, which may be social, aesthetic or financial, thus, there could be three master programmes in 2010/2011 featured:

1. "Creative and Cultural Entrepreneurship": this program helps to get entrepreneurial skills and teaches how creative and cultural knowledge and/ or practice can be commercialised. There are historical and theoretical 
knowledge and understanding of creative and cultural industries as well as the development of the creative economy emphasized.

2. "Arts and Cultural Policy Administration": this program offers the chance to learn how to combine the applied arts, culture, politics and art administration areas.

3. "Social Entrepreneurship": social entrepreneurship started being taught in 2011, a unique environment to study and explore the field of creative and cultural entrepreneurship and other areas related to entrepreneurship, such as the cultural urban restoration, new models of theatre or music production or new ways of thinking in the design and accessibility.

The School of Management at the University of St. Andrews in Scotland develops "Masters in Creativity Management" Program, which prepares specialists understanding creative processes, possessing necessary qualities, business planning, financial management knowledge and willing/to use them in practice.

The culture and creativity-based Master program "Culture, Creativity and Entrepreneurship" at the University of Leeds, Faculty of Performance, Visual Arts and Communications, is oriented to the preparation of professionals in the fields of culture and creativity. The Aalto University in Helsinki carries out postgraduate studies "Creative Sustainability" and "Creative Business Management". These master programs seek to build a sustainable future where skills of making creative decisions are developed for a sustainable living, urban development, environmental protection planning, and production services; therefore, multi-disciplinary specialists able to work with experts from different areas are prepared. The program aims to promote the sustainability through the creative design and innovations.

The Faculty of Arts at the Chinese University of Hong Kong held the Master program "Cultural Management": students began studying in 2001, and this was the only program of such specification in the country. By studying "Cultural Management" students are prepared for the collision with the rapidly changing environment of creative industries within the global culture. Within the program students are educated not only in management sciences, but also in the co-operation of culture with the ethics, in the field of creators' rights, social and political sciences. Future specialists are eliminators of the gap between the cultural and social integrity, activists and protectors of their rights and etc. The Hong Kong Institute (called The Hong Kong Institute of Education) hold the bachelor's program which starts 2011/2012 "Creative Art and Culture."

The first undergraduate program "Creative Arts and Culture" is prepared at the Hong Kong Institute of Education for the year of 2011/2012, offering arts management and cultural studies. The program aims to prepare professionals with such knowledge as communication, management or finance. The College of Economics and Business at the Australian National University in the co-operation with the College of Arts and Social Sciences, prepared a double bachelor degree program "Bachelor of Music and Trade."

The University of Melbourne prepared a Master program "Cultural Management", which is oriented to managers of a variety of creative industries, such as dance, theatre, music and arts. The program focuses on management and creative production, emphasizing the co-operation in developing the knowledge in areas of law, management and policy. Another Australian University, the University of Canberra, offers a variety of undergraduate programs with a dual diploma, such as "Arts and Marketing", "Arts and Law", "Arts and Public Relations". Having a look at a positive experience of European universities, the Copenhagen Business School in Denmark offers a new undergraduate program "Business, Language and Culture". Thus, the knowledge of culture is an excellent choice of languages (French, German, Spanish) and an international experience during the final year of studies (students are studying at universities of countries whose language they are studying) as well as the reunion of business, language and culture make a perfect fit of living and working in a modern society. To continue, the Master program "Arts Administration" is developed at the Florida State University in North America.

Thus, universities in many countries have already introduced both undergraduate and postgraduate programs in raising the number of modern, creative members of the society when other universities are just starting implementing such programs. Especially it is noticeable that programs at different higher education institutions and universities are oriented to double and joint diplomas enclosing such fields as creative business management and creative leadership. However, it could be stated that the creativity and entrepreneurship education are the most notable at European universities, followed by Asian and North American universities.

Meanwhile, such countries as Afghanistan, India, and New Zealand do not have programs related to the creative public. It is also possible to conclude that implementation of such kind of programs in the higher education system is associated with the world's on-going creative international trade in goods and services, where it is 
clearly visible a regional economic growth. Lithuanian universities currently only start launching analogous postgraduate studies in drawing up the creative economy; for instance, a very similar program could be found at the Kaunas Faculty of Humanities at the Vilnius University, where within the "Cultural Management" program specialists developing cultural activities, entertainment business, artistic and cultural events, projects and working with the media are prepared. The Vilnius Academy of Fine Arts held the Master program "Cultural Policy and Cultural Management", and the Vilnius Gediminas Technical University held the Bachelor program "Creative Industries", which gives knowledge of corporate and business development in the context of the creative economy. International Business School at Vilnius University offers the opportunity to study in "Creative Business" graduate program. These are only few examples of global universities' attempts to link arts with business via the education system.

According to Eurostat (2007), during the period of 2004-2005 the largest percentage of students studying arts was in Malta (10.9\%), and the lowest in Poland (only 1.0\%), while the data on students, whose education is related to arts, by gender shows that the largest percentage of female students was in Latvia 73,3\%; the largest percentage of male students involved in cultural studies among 27 European Union countries was in the field of architecture $(64.1 \%$ ), compared to $61.5 \%$ of female students studying arts. According to co-authors of the Feasibility Study of Lithuania (2008), Lithuanian study programs, related to cultural and creative industries, do not reflect the true situation, since the Department of Statistics provides the data on the basis of the classification of education in Lithuania, where cultural and creative industries are not singled out; for these reasons authors base their results on the data of two high schools, the Academy of Music and Theatre and Vilnius Academy of Fine Arts that prepare programs exclusively liaised with creative and cultural industries, mainly relaying on the Lithuania's education classification. Thus, co-authors present such institutions in Lithuania that prepare creative and cultural industry professionals: Universities (Vilnius Gediminas Technical University, Lithuanian Academy of Music and Theatre, Vilnius Academy of Fine Arts, Vilnius Pedagogical University, Kaunas University of Technology, University of Klaipeda, Šiauliai University), colleges (Vilnius College, Kaunas College, Marijampole College, Vilnius College of Technologies and Design).

The creative and cultural industries-related study programs are famous by training customizable artistic skills; the Lithuanian Academy of Music and Theatre and the Vilnius Academy of Fine Arts organize the first (undergraduate), second (graduate) and third (doctoral) degree programs for professionals of arts such as the Graphics, Photography, Design, Architecture, Performance Art, Musicology, Acting Art, Music Management, and etc. Though these Lithuanian universities and colleges develop similar creative industries and cultural programs, co-authors note that they do not often develop the ability to apply the acquired professional knowledge and skills in the field of creative industries; entrepreneurship is poorly educated, while the content of those programs is not always adequate to creative industries' needs and lacks the co-operation with creative industries' enterprises and technological equipment as well as artistic skills training tools and instruments (including teaching material for lectures) (Antanavičiūtè et al. 2008). The study also draws attention to the fact that these problems are also complemented by a small number of specialists, the lack of technical literature and researchers' motivation and/ or maintenance problems. Thus, it should be kept in mind that the creativity and innovations, entrepreneurship and teamwork, co-operation and competition in creative industries are very important, because management and creativity in creative and cultural industries are closely related (Antanavičiūtè et al. 2008).

In many literature sources, the creativity is related to talent management, which according to Cappelli (2008), should be analysed from a human capital perspective. Farndale et al. (2010), add a business strategy and corporate culture as important factors in talent management, and some authors elucidate the role of national contexts (Luthans et al. 2006; Vance and Vaiman 2008; Vaiman et al. 2012; Mellahi and Collings 2010; Tymon et al. 2010; Scullion and Collings 2010; Collings et al. 2011). The talent development is a part of the talent management process, which incorporates planning, selection and implementation of development strategies in order to meet the market needs and organizational targets (Garavan et al. 2012).

As it is recognized by experts of the Quality Assessment Centre, foreign partners, cultural, arts and educational institutions employing graduates, the level of preparation of arts specialists at Lithuanian universities is relatively high (Antanavičiūte et al. 2008). However, business representatives state that graduates have only a theoretical knowledge and suggest to involve the best cases of creative and cultural industries combining the creativity with entrepreneurship, as well as to implement the compulsory practice in creative and cultural industries' companies. Although study programs are constantly updated, and only highly skilled or recognized 
artists teach, creative and cultural industries' and other economic sectors' needs indicate that these updates are not sufficient, because the program does not provide entrepreneurial trainings, the legal knowledge and understanding of needs of the market; there is still a weak co-operation between universities and the business community.

Young students' needs and requirements are also significantly higher than the higher education organizations can provide; classrooms, equipment and technologies are outdated or depreciated (for example, musical instruments; the lack of modern working equipment, for example in music), while the study programs that are not in line with the cultural and economic development needs of the country are not updated. There is also the lack of international co-operation witnessed, making it difficult to remain competitive in terms of studies, it is difficult to invite highly qualified scientists, which hampers the studies' quality, resulting in many young and talented artists leaving to work and study in other countries. Trying to catch up the EU economies, Lithuania's education system should adapt to economic changes and requirements. Co-authors believe that the larger competition from diverse and demanding markets, the uncertainty, and technologies the creative business faces the more important are management abilities (Antanavičiūte et al. 2008). It is emphasized that the number of lifelong learning people is modest in Lithuania, while resources and motivation are insufficient. However, co-authors note that in recent years the teaching staffs is aging and the professional knowledge is becoming unsuitable for requirements of the today's professional qualification (Antanavičiūte et al. 2008). The available equipment no longer meets modern requirements, making it difficult to carry out the research meeting the business requirements and, at the same time, participating in international research projects. As the reasons for the transition to other activities or the brain drain issue very low salaries of teaching and research staff as well as a fragile prestige of teachers and researchers in the country are highlighted. According to co-authors, it is important to develop a necessary infrastructure, having a greater emphasis on the coordination of investments, to improve the intellectual property protection, to promote investments as well as to develop the co-operation between sciences and business. The feasibility study proposes to set up the centre of coordinating a scientific potential (creating innovative products), to use the knowledge of scientists and creative ideas of artists in order to get real benefits for a sustainable product development, to provide information services (decision-making, counselling, etc.), to ensure access to databases of a scientific information, to promote creative industries' activities to the general public and etc.

Meanwhile, while monitoring trends in the choice of study area, it is noted that among applicants to Lithuanian universities and high schools in 2010 social sciences were the most popular with such specialties as Economics, Law, and Political Sciences. The entrants do not know what will the market needs be in the future and choose those professions the knowledge of which can be applied in various sectors today. During the accession year of 2010, among students studying for free (i.e., the state-funded places) the highest accession scores were in the applied textile, arts, fashion design, clothing, decorative plastics and others. Thus, it is noted that in many countries around the world programs, related to the creative economy and creative industries, are receiving the increasing momentum, which is not random, but is based on the rapidly evolving world of the international trade in creative industries' goods and services. All this leads to the enhancement of knowledge and innovations as well as to the contribution of high technology-intensity activities to the GDP.

\section{The wider Europe for future generations}

The global financial crisis has changed the economic situation and the emergence of new threats to social cohesion becomes possible. According to Jose Manuel Barroso, Europe needs to get back on track, and it must stay on track (European Commission 2010c). This is the target of the European Strategy 2020 (European Commission 2010c). Witnessing many changes worldwide, especially within the economic and social progress, hit by the financial crisis, it became difficult to invest or spend; a lot of investment plans and ideas fail, it became difficult to borrow and ensure the economic growth. Even before the crisis the European Union in many areas lagged behind other countries in terms of investments in innovations, researches, technological development and employment. It is aggravated by the Europe's aging society, resulting in the decreasing number of employees.

There is also the increasing competition from other developed and developing countries such as India and China visible; these countries have invested a significant part in the research and technology in order to raise the competitiveness of their industry. The crisis has also revealed that European Union countries are closely interrelated, particularly countries belonging to the Euro Zone, as there is the indirect effect seen (the reform in 
one country affects other countries' economic performance), which shows the importance to simultaneously execute strategic steps in order to overcome the crisis and reach positive results. Thus, Europe faces a difficult choice in addressing challenges of the economic recovery: "Sustainable recovery", "Sluggish recovery" (the continuation of a slow reform, which is resulting in a low growth rate) "Lost decade" (experiencing a relative decline) (European Commission 2010c: 8).

In spite of all these difficulties, Europe was able to prove the world being able to create the world's largest single market and single currency, to prevent the further economic collapse as well as be proud of talented people, their creativity, thriving agriculture, the largest trading bloc and foreign direct investments, values, democracy and solidarity, cultural diversity, respect for the gender equality. To ensure a high quality of life for future generations the European Union has to take care of the future and take on responsibilities and commitments to improve the situation. Therefore, in 2010 the European Commission prepared the Strategy for Smart, Sustainable and Inclusive Growth (2020), where the European Union seeks a high level of employment, productivity and social cohesion (European Commission 2010c). For these reasons the selected objectives must be completed by 2020:

1. The employment of the population within the age group 20-64 should increase from $69 \%$ to at least $75 \%$, better integrating immigrants into the labour market;

2. 3\% of the EU GDP should be invested in the research and development, facilitating the private sector;

3 . There should be " $20 / 20 / 20$ " climate and energy targets implemented, reducing the greenhouse effect by $20 \%$, to increase the use of renewable resources by $20 \%$, to improve the efficiency in energy use by $20 \%$ (including the reduced gas emissions by $30 \%$ );

4. The share of early school leavers should not exceed $10 \%$, and at least $40 \%$ of the younger generation should acquire higher education;

5. The number of Europeans living below the national poverty level should be reduced by $25 \%$.

All these objectives are closely interrelated; a better education leads to employment opportunities and, therefore, reduces the poverty; there are new technologies introduced, researches carried out and the creative society developed. The European 2020 strategy has three key priorities of the European Union (smart growth, sustainable growth, inclusive growth); the Commission proposes to make these priorities as national objectives and guidelines. To implement these priorities at the national, European and international level, the Commission presents seven initiatives (European Commission 2010c):

1. Smart growth - strengthening the knowledge and innovations, improving the education system, lifelong learning (only one among three people of the age 25-34 has the university education in Europe; European Commission, 2010), research promotion (the European R\&D expenditure is less than 2\%), aims to turn ideas into innovative products and/ or services, resulting in promoting creativity.

1.1. "Innovation Union" is related to the establishment of the research area to promote business innovations, the support for innovations, enhancement of the co-operation between the education and business.

1.2. "Youth on the Move" is oriented to the modernization of a higher education and enhancing the mobility programs of researchers and universities, promoting entrepreneurship, youth employment, investment in education, integration into the labour market.

1.3. "Digital Agenda for Europe" is to more rapidly develop a high-speed Internet and to ensure households' and businesses' access to the common digital market.

2. Sustainable growth is a more economical use of resources, leadership in the clean technology, increasing renewable energy use.

2.1. "Resource-efficient Europe" is to support the resource-efficient technology.

2.2. "Industrial Policy for the Globalization Era" is to compete globally, to support the business, in particular micro, small and medium-sized companies.

3. Inclusive growth is to guarantee employment for people, to renew the labour market, to take care of the social security, investments in human skills (lifelong learning opportunities are perceived and used by more educated people) to fight the poverty (people whose salary is not enough to overcome the poverty threshold).

3.1. "New Skills and Jobs Agenda" is to give people the opportunity to improve skills all their life, to increase the labour supply and its mobility.

3.2. "European Anti-Poverty Plan" is to provide conditions for everyone to take advantage of new jobs offered to the poor and socially excluded residents to live in the dignity and participate in community activities. 
In order to ensure the welfare of future generations, one of the key aspects of the creative society is the mobility, which opens up great opportunities, not only the knowledge and skills, but also the promotion of the cultural diversity. "The creativity is born at a local level, but its effects can be spread throughout the world" (European Commission 2010: 12). For this reason the promotion of artists' and creators' mobility could allow the access from the local to global levels, increasing the visibility and attractiveness. The mobility contributes to the development of skills among artists and cultural professionals, the artistic development, wider career opportunities (exchange programs, international exhibitions, and festivals), supporting emerging talents and the diversity of the cultural knowledge. The European Union carries out the international cultural exchange and trade activities in accordance with the UNESCO Convention on Cultural Diversity and Promotion (2005) (European Commission 2010). In accordance with this Convention, the European Union is in line with principles of the equal opportunity, openness and balance, based on the international co-operation, cultural exchanges, solidarity and partnership; thus, demonstrating the openness to other cultures of the world.

In 2009, the Council of the European Union provided findings related to the creativity of a younger generation (the encouragement of creativity and innovative skills of children and young people through a cultural expression and access to culture). These findings are to ensure a global competitiveness, to promote a cultural dialogue, to reduce gaps among the member states in terms of developing skills of children and young people in the field of creativity and innovations, entrepreneurship promotion, the knowledge of arts from an early age, collaboration with artists, enhancing the creativity and innovations of children and young people, promotion of the culture in educational organizations and the access to culture for children and young people. To encourage the creativity of a younger generation, the Council of the European Union (2009) has identified six priorities: to involve children and young people in the promotion of cultural policies, to optimally exploit the potential of the educational sector in order to enhance the creativity through the culture and cultural expressions, promotion and sponsorship of cultural institutions, including children and the youth; talent and creativity encouragement through the culture; executing social inclusion strategies for children and young people; a better access to the culture while encouraging the use of ICT (information and communication technologies) for all children and young people; facilitating the exchange of good practices and developing the evidence-based knowledge in this area.

The early stage education and creativity encouragement are crucial for a better performance of entrepreneurs. It could be explained via lowering the uncertainty avoidance in a country (in many cases leading to a smaller fair of failure) and developing skills to acknowledge existing capabilities in the market along with skills and knowledge. Thus, the further sections of the article are to present the Global Entrepreneurship Monitor-based research methodology and examine the role of creativity on entrepreneurship in the context of the symbiosis of arts and business.

\section{The research methodology}

Having the main trends of developing the culture worldwide, the role of culture for a sustainable EU social and economic development, and the role of education in bridging the creativity and business well developed in the previous sections, the publication is continued by the examination of the role of creativity in Lithuanian business, based on the data of Global Entrepreneurship Monitor (GEM 2011). In this way, insights and arguments on the role of creativity on entrepreneurship are supported by results of GEM (2011). Lithuanian entrepreneurs and entrepreneurship-related experts are the principle focus within the research.

The data of the Lithuanian Entrepreneurship Monitor is collected from two researches, based on the GEM methodology. The research was conducted in September 2011 by the team of the International Business School at Vilnius University, composed of 5 members. While conducting the research, the International Business School at Vilnius University was tightly cooperating with the public enterprise "Enterprise Lithuania", which showed a continuous support and assistance.

The first research is the quantitative survey, where 2003 Lithuanian adults of the age group from 18 to 64 are interrogated. In general the adult survey is to identify the citizens' role and characteristics in entrepreneurial activities, while the focus of the article is on the role of the creativity. Therefore, only the data related to the creation process and creativity is taken into consideration in the context of the entrepreneurship. 43 per cent of interviewed respondents had a higher education. Two groups of respondents were specified: respondents who 
start or help to start a business without revenues received yet $(\mathrm{N}=255)$ and respondents who are already owners of their businesses $(\mathrm{N}=307)$.

The second research is the qualitative experts' interview, driven by the purpose to identify the experts' perception towards the main factors driving entrepreneurship activities in the country as well as a social image of entrepreneurs. There were 36 experts interviewed from such fields as finances, governmental programs, education and training, $R \& D$, business and physical infrastructure, market openness as well as cultural and social norms in Lithuania.

A social image was an additional group of questions, initiated by the Lithuanian team. Although a social image of entrepreneurs derived from three main groups of factors (the citizens' opinions, social norms and support and the perceived opportunities and skills) the present publication is mainly oriented to the aspect of creativity, as it is an important link of arts and business.

To achieve the target of the article, which is the identification of the role of creativity in businesses, first of all it was tried to understand the citizens' attitude regarding entrepreneurship, particularities of entrepreneurial activities, entrepreneurs' education as well as the attractiveness of their career. These insights were followed by social support while choosing a businessman career; and the last aspect was related to the perception of their capabilities and skills to start a business.

Although the Lithuanian Entrepreneurship Monitor (2011) was related to the specificity of the Lithuanian market, it allows the policy makers and researchers to position Lithuania in terms of Entrepreneurship among other countries, and it could be of an important value for further analysis and conceptual modelling, related to possibilities of linking arts and business via the creativity.

\section{The role of creativity in business}

The analysis of the role of creativity in business could be started from briefly describing the Lithuania's entrepreneurship profile, while positioning it among other countries. As it is stated in the 2011 GEM report, Lithuania is being globally ranked at the 40th place, based on the Human Development Index and the Global Innovation Index (2011) (in 2012 Lithuania occupies the $38^{\text {th }}$ position, according to the Global Innovation Index ranking), and reaches the 27th position regarding the Doing Business Index. The main strengths of the Lithuanian entrepreneurial performance are the total early-stage entrepreneurial activity, as a medium-high job expectation, and the entrepreneurial employee activity (EEA). A relatively low global ranking, according to the perception of happiness - Happy Planet Index (120/151 in 2012), is accompanied by low figures of perceived opportunities and capabilities. These aspects significantly contribute to the creativity in businesses.

Lacking behind many countries belonging to the innovations-driven group and some countries from the efficiency-driven group Lithuania possesses citizens with rather positive opinions about entrepreneurs. In 2011 more than half of the population believed that businessmen worked harder than representatives of other professions, 47,7 \% of respondents considered entrepreneurs as highly educated, while 47,5\% admitted that Lithuanian entrepreneurs thought only about their pockets. It should be added that $83,7 \%$ of Lithuanian citizens appreciated the entrepreneurs' role in creating new job positions in the market. Overall $45 \%$ of the population found out more advantages than disadvantage of being an entrepreneur.

Coming back to the previously disused links of arts and business, the creativity is one of the most important linking elements; however, the concept of creativity is not clear and across businesses manifests in various forms and characteristics. One of them is innovations and 'being innovative', as new processes, products and services are always human resources-intensive, while the knowledge diffusion among members of an organization and strategic management of human resources should encourage the creativity. Based on GEM research results (2011), only less than $15 \%$ of respondents do not agree that entrepreneurs are innovative (45\% agree with the statement). A positive social image of entrepreneurs (one third of the population positively evaluate Lithuanian businessmen) and an energetic power of business people (more than $70 \%$ agree that entrepreneurs are energetic) emerge as important drivers of the Lithuanian national innovation system, where the creativity is of significant importance.

The creativity could be also imprisoned by the risk-aversive attitudes, as nearly half $(49,8 \%)$ of respondents afraid to start business because of the necessity to manage risk well. It is interesting to note that in 2012 the entrepreneur's profile switches from the necessity to opportunities-driven business; however, it is accompanied 
by the decrease in the total early-stage entrepreneurial activities, which indicates appearing good opportunities in the labour market (GEM 2012).

Based on annual GEM results (2011), Lithuania was closer to the innovation-driven group of countries than to the efficiency-driven countries regarding figures related to entrepreneurship, which could be described as the employees' entrepreneurship. This is a partly favourable indicator, as the entrepreneurship is also related to the creative incentives and innovative activities of employees. On the other hand, it indicates that respondents afraid to be creative and innovative running business alone, without being linked to their current or past employer. While working in organizations (63,1\% of respondents) $19,1 \%$ respondents were active in creating or executing new activities for their employer.

As it is argued by Laužikas and Dailydaite (2013), it is useful to have a look at leadership skills in generating innovative ideas. The concept of idea and invention is often confused with the notion of innovation. Without naturally emerging leaders and formal process of commercializing innovative ideas it is impossible to generate a value-added. The fact that more than one third of respondents managed the process of generating innovative ideas, more than half of respondents helped to generate those ideas, and 57,4\% of respondents were involved in the preparation or execution process shows the sustainability of innovation processes: many respondents cross different stages of the innovation development process, not stopping at the stage of generating innovative ideas (Laužikas and Dailydaitè 2013).

Relying on Lithuanian experts' arguments, the role of education and training is crucial in enhancing the citizens' creativity; however the present education system in Lithuania pays insufficient attention to the creativity and creation of new businesses. Based on their opinions, the orientation to entrepreneurship is the most vacant in primary and secondary schools (stated by nearly two thirds of experts). $50 \%$ of experts consider the situation in colleges, universities, business trainings better in preparing graduates able to create and develop their own businesses. The professional, vocational and continuous education is evaluated at the highest rank (only one third of experts valuate it pessimistically). Some important signals, according to more than two thirds of experts, should be sent towards the role of national culture in encouraging risk-taking while developing entrepreneurial activities as well as the creativity and innovativeness (more than half of experts are not satisfied with the national culture in boosting the creativity).

Apart from the cultural support, entrepreneurial activities should be accompanied by a necessary set of knowledge, skills and experience: $86 \%$ of GEM experts strengthen that people do not have sufficient experience to commence a new business or to develop a rapidly growing business. Over $70 \%$ of respondents state that people are not able to react and organize necessary resources for business. This calls us back to the previously discussed role of education, particularly of study programs that merge the business and arts, with a special emphasis on entrepreneurship and creativity. However, the cultural support, education initiatives are not enough to merge the business and arts. The protection of intellectual rights, trademarks and patents should be guaranteed in order to encourage the creativity and inventors' potential. Based on GEM experts' responses (2011), the intellectual property rights are weakly protected in Lithuania, which emerges as a serious barrier for young creativity-driven businesses.

The perception of the role of innovations among firms and consumers is related to the percentage of answers regarding what part of potential consumers (all, a part, no one) will perceive products and services as innovative: $54,8 \%$ of respondents who are involved in the process of business creation do not believe that consumers will consider their products and services as innovative, while $52,8 \%$ of respondents feel a severe competition in the market. More than two thirds of respondents, who already own their business, believe that their offered products and services are not innovative. Similar situation is across all the analysed sectors, such as Mining sector/ Agriculture, Technology-intensive sectors, Goods and Services for Consumers, Business Goods and Services. Notwithstanding such demanding data, it is pleasant to know that all the mentioned sectors experience a slightly positive transformation towards the innovations-driven businesses and a better positioning among competitors via a more ingenious market analysis and strategic management techniques.

The present section of the article is terminated by presenting the conceptual model of the role of creativity in sustainable business which could be used for the further research on the combination of business and arts (Figure 1). 


\begin{tabular}{|c|c|}
\hline $\begin{array}{l}\text { Location; } \\
\text { Infrastructure; } \\
\text { Protection of intellectual } \\
\text { rights, trademarks and } \\
\text { patents; } \\
\text { Policies and programs; } \\
\text { Financial resources }\end{array}$ & $\begin{array}{l}\text { Innovations and } \\
\text { 'being innovative'; } \\
\text { The R\&D diffusion; } \\
\text { The use of modern } \\
\text { information } \\
\text { technologies }\end{array}$ \\
\hline $\begin{array}{l}\text { Perception of business } \\
\text { opportunities; } \\
\text { Perception of personal }\end{array}$ & $\begin{array}{l}\text { Intrapreneurship = } \\
\text { employees' } \\
\text { entrepreneurship }\end{array}$ \\
\hline $\begin{array}{l}\text { The role of education } \\
\text { and training; } \\
\text { Necessary sets of } \\
\text { knowledge, skills and } \\
\text { experience }\end{array}$ & $\begin{array}{l}\text { executing innovative } \\
\text { ideas; } \\
\text { Necessary initiatives } \\
\text { and efforts }\end{array}$ \\
\hline $\begin{array}{l}\text { Cultural and social } \\
\text { norms; } \\
\text { Risk-aversive attitudes } \\
\text { and other cultural } \\
\text { dimensions }\end{array}$ & $\begin{array}{l}\text { Orientation to niche } \\
\text { and innovations; } \\
\text { Strategic } \\
\text { management and } \\
\text { market analysis; } \\
\text { Sustainable growth } \\
\text { and competitive } \\
\text { advantages }\end{array}$ \\
\hline
\end{tabular}

Fig.1. The role of the creativity in business Source: prepared by authors, based on the Lithuanian GEM (2011) report

First of all there should be a set of factors influencing the enhancement of creativity identified. As it was stated by our experts (GEM Lithuania 2011) some factors are more of exogenous nature; it is unlikely possible to rapidly change a location, infrastructure, protection of intellectual rights, trademarks and patents, governmental policies and programs or the availability of financial resources; however, all of them are of significant 
importance for the creativity. These factors are accompanied by the perception of business opportunities and personal knowledge, skills and experience that are mainly influenced by the education and training as well as cultural and social norms.

Allocating funds for creativity is wise for many reasons: the thing that the creativity emerges in forms of innovations, $R \& D$ or technologies advices managers to tackle all the creativity-related issues as the main priority. It is also necessary to enhance employees' entrepreneurship which is directly related to leadership skills in generating and executing innovative ideas, necessary initiatives and efforts. Having no creative and innovative thinking on board as well as no funds or formal process to enhance the creativity within the organization the orientation to niches and innovations is endangered, while strategic management and market analysis do not focus on a sustainable growth and competitive advantages.

\section{Conclusions}

Within the cultural exchange, development policies or external relations the cultural dimension is crossing the boundaries of the European Union. It promotes the solidarity, opens new possibilities of international economic and social relations, mobility exchanges and the access to goods and services of various cultures. It is becoming a global trend to focus on preparing a larger number of innovative and creative people capable to understand the mutual relationship and synergies between arts and rapidly changing global business world. The implementation of study programs that merge arts and business is associated with the world's on-going creative international trade in goods and services. Though the Lithuanian education system currently does not possess a vast assortment of postgraduate studies in developing the creative economy, there could be some minor exceptions found.

The initiatives to encourage the creativity of a younger generation at the EU level (six priorities stated by the Council of the European Union) should be accompanied by evident efforts at a country's and company's level. Taking into consideration that the creativity emerges in forms of ideas, entrepreneurial initiatives, innovations, $\mathrm{R} \& \mathrm{D}$, technologies, managers should tackle all the creativity-related issues as the main priority. Employees' entrepreneurship is directly related to leadership skills in generating and executing innovative ideas, necessary initiatives and efforts; thus, having no creative and innovative thinking on board as well as no funds or formal process to enhance the creativity it could be difficult to achieve a sustainable growth and competitive advantages of businesses.

\section{References}

Antanavičiūtè, R.; Gelūnas, A.; Juodelienè, A. 2008. Lietuvos kūrybinès ir kultūrinès industrijos [Cultural and creative industries in Lithuania]. Galimybiu studija. Vilnius: 91 p. Available on the Internet: <http://lmta.lt/web/pdf/>.

Ashley, C.; Oliver, J. D. 2010. Creative Leaders. Thirty Years of Big Ideas, Journal of Advertising 39 (1): 115-130. Available on the Internet: <http://web.ebscohost.com/ehost/pdfviewer>.

Cappelli, P. 2008. Talent on Demand: Managing Talent in an Age of Uncertainty. Harvard Business Press, Boston, MA. 304 p.

Collings, D. G.; Scullion, H.; Vaiman, V. 2011, European perspectives on talent management, European Journal of International Management 5(5): 453-462.

European Commission. 2007. Communication from the Commission to the European parliament, the Council, the European economic and social committee and the committee of the regions on a European agenda for culture in a globalizing world, 10.5.2007 KOM. Brussels. Available on the Internet: <http://eur-lex.europa.eu/LexUriServ/LexUriServ.do?uri=COM:2007:0242:FIN:EN:PDF >.

European Commision. 2010a. Green Paper on the potential of cultural and creative industries. Brussels, 2010.4.27, KOM(2010) 183 (final). Available on the Internet: 〈http://europa.eu/legislation_summaries/culture/cu0006_en.htm >.

European Commission. 2010b. Commission Report to the European Parliament, the Council, the European Economic and Social Committee and the Committee of the Regions of 19 July 2010 on the implementation of the European Agenda for Culture, 2010 KOM 390 (final). Available on the Internet: <http://ec.europa.eu/culture>. 
European Commission. 2010c. A strategy for smart, sustainable and inclusive growth. Europe 2020. Available on the Internet: < http://ec.europa.eu/eu2020/pdf/COMPLET\%20EN\%20BARROSO\%20\%20\%20007\%20-\%20Europe\%202020\%20-

$\% 20 \mathrm{EN} \% 20$ version.pdf $>$.

European Parliament. 2008. The Implementation by the European Community of the UNESCO Convention on Cultural Diversity. Available on the the Internet: http://www.europarl.europa.eu/document/activities/cont/200802/20080227ATT22450/20080227ATT22450EN.pdf >.

Eurostat. 2007. Available on the Internet: 〈http://epp.eurostat.ec.europa.eu/portal/page/portal/eurostat/home/〉.

Farndale, E.; Scullion, H.; Sparrow, P. 2010. The role of the corporate human resource function in global talent management, Journal of World Business 45(2): 161-168.

Garavan, T. N.; Carbery, R.; Rock, A. 2012. Mapping talent development: definition, scope and architecture, European Journal of Training and Development 36(1): 5-24.

Global Entrepreneurship Monitor Report, Lithuania. 2011. Available on the Internet: 〈http://www.tvm.vu.lt/lt>.

Global Entrepreneurship Monitor Report. 2012. Available on the Internet: 〈http://www.gemconsortium.org/〉.

Gong, Y.; Jia-Chi, H.; Jiing-Lih, F. 2009. Employee learning orientation, transformational leadership, and employee creativity: the mediating role of employee creative self-efficacy, Academy of Management Journal 52(4): 765-778. Available on the Internet: <http://www.bm.ust.hk/mgto/staff/papers/yaping/AMJ-2009.pdf>.

Hill, M. E. 2003. The development of an instrument to measure entrepreneurship: entrepreneurship within the corporate setting, Master paper, Grahamstown, Rhodes University. 209 p.

Laužikas, M.; Dailydaite, S. 2013. Benefits of social capital for sustainable innovation capabilities, Journal of Security and Sustainability Issues 2(3): 85-97. doi: 10.9770/jssi.2013.2.3(7)

Luthans, F.; Zhu, W.; Avolio, B. J. 2006. The impact of efficacy on work attitudes across cultures, Journal of World Business 41: 121-32.

Mainemelis, C. 2010. Stealing fire: creative deviance in the evolution of new ideas, Academy of Management Review 35(4): 558-578. Available on the Internet: 〈http://web.ebscohost.com/ehost/pdfviewer〉.

Mellahi, K.; Collings, D. G. 2010. The barriers to effective global talent management: the example of corporate e'lites in MNEs, Journal of World Business 45 (2): 143-149.

Meyers, H.; Gerstman, R. 2007. Creativity. Unconventional Wisdom from 20 Accomplished Minds. N.Y. ISBN-13:978-0-230-00134-3. $236 \mathrm{p}$.

Scullion, H.; Collings, D. G.; Caligiuri, P. 2010. Global talent management, Journal of World Business 45(2): 105-108.

The Council of the European Union. 2009. Creative Generation: developing the creativity and innovative capacity of children and young people through cultural expression and access to culture. C 301/9. Available on the Internet: <http://eurlex.europa.eu/LexUriServ/LexUriServ.do?uri=OJ:C:2009:301:0009:0011:EN:PDF>.

Tymon, W. G.; Strumpf, S. A.; Doh, J. P. 2010. Exploring talent management in India: the neglected role of intrinsic rewards, Journal of World Business 45(2): 109-121.

Vaiman, V.; Scullion, H.; Collings, D. 2012. Talent management decision making, Management Decision 50(5): 925-941. doi: 10.1108/00251741211227663

Vance, C. M.; Vaiman, V. 2008. Smart talent management: on the powerful amalgamation of talent management and knowledge management. Smart Talent Management: Building Knowledge Assets for Competitive Advantage. Edward Elgar, Northampton, MA, 115. 